\title{
TRANSLATING KOREAN NATURE. TRANSLATION STRATEGIES IN LITHUANIAN AND ENGLISH LITERARY TRANSLATION
}

\author{
LORA TAMOŠIŪNIENE் \\ Mykolas Romeris University, Lithuania \\ lora@mruni.eu
}

\begin{abstract}
World literatures today often impose a separation of narratives from their geographic and linguistic origins. Translated versions of literary texts that were created and received within local cultural contexts, when translated, enter new, foreign contexts. When translations into many other languages appear, a writer may expect many diverse valuations of one's work. Literary texts in translation, in fact, are an inseparable from literary experiences for many readers and the study of translated texts has a long-standing tradition. The future of such texts may also lie in the emerging future reading - "distant reading" to quote Walkowitz' use of Moretti's term. Among the strongest arguments in support of such reading is the possibility, through translated texts, to establish a more aesthetic distance towards the object of a fictional text in translation. Translation gives us as readers a new and different approach towards objects we fail to notice because of their familiarity. Nature scenes and objects may be included among such features of the narrative that could be more aesthetically appreciated in the translated versions. The paper compares translations of nature scenes and objects of Shin Kyung-Sook's novel into English Please Look After Mom (2011) and into Lithuanian Prašau, pasirüpink mama (2019). The paper reveals the scope of translation strategies of domestication and foreignization through comparison of translation of nature scenes and items into Lithuanian and English.
\end{abstract}

Keywords: literature in translation, nature in literature, Shin Kyung-Sook

\section{Introduction}

Attention to the translated literature is gaining the momentum. Since 2016 The Man Booker International Prize officially has been celebrating translators on a par with the authors. Many countries curate their literary representation via translators` support programmes, institutions and education. The work of the literary editors and literary critics who may not be able to read in the language the work of literature was originally conceived may appear to prove its value. It is a long- established practice to compare translations into different languages and these processes should claim recognition and appreciation. Tim Parks, an eminent 
British scholar limits one`s appreciation of a translated work of literature to a thorough study of such translation into one's own language of convenience. In his essay "Raw or Cooked?" he states:" How can I judge a translation if I don't know the original language? Time and again fellow reviewers have raised this question with me. [...] I have but one resource. I must consider the relationship between content and style in the English translation." (Parks, 2016). In the same essay Parks goes as far as to maintain that translated texts aim at reconstructing the relationship between content and style, the relationship that is "inseparable" in a literary text.

Using the translated sources, in fact, has been a standard institutional practice in the humanities, academic courses, programmes, concentrations. All these projects have often rested on texts that were studied in translation, and such practice might have led to a possibility to "highlight everything that the exclusive focus on a national literature tends to obscure "(BU, 2019). Translation of literature makes studying of multilingual literatures available and, in this capacity, is explicably endorsed in many academic essays in comparative literature studies. Rebecca L. Walkowitz in her essay Unimaginable largeness: Kazuo Ishiguro: Translation and the New World Literature redefines current understanding of world literature, she states: “... the new world literature - now is understood as literature that circulates outside the geographical region in which it was produced" (Walkowitz, 2007:216). In fact, the relevance of translated literary texts is supported by the future reading tendencies, as Walkowitz puts it "distant" reading practice of the texts in translation (Walkowitz, 2015:67). Walkowitz makes use of Franco Moretti's idea that any new narrative pattern must be a reflection of already existing basic recognizable patterns. This new, "distant" horizon of reading provides readers with a new approach towards objects that fail to be noticed when read in their native languages because of the familiarity of such objects. Among such objects, nature scenes and nature items in the translated texts of fiction may stop the attention of the reader for better or for worse or may pass unnoticed depending on the chosen translation strategy which, in effect, controls the appreciation of a literary translation.

This article applies the measure of two broad translation strategies, domestication and foreignization as introduced by an American scholar Lawrence Venuti, who, in his turn, is referring to Schleiermacher's introduction of two methods of dealing with a foreign text. The first method of coping with the "otherness" of foreign linguistic and literary realia is domestication or an "ethnocentric reduction of the foreign text to values of a target-language" (Venuti, 1995:20). The second method of translation is the method of foreignization, "ethnodeviant pressure on cultural values of a target-language". In Venuti's understanding domestication provides a more economic and smoother translation of a foreign text, however, readers are trapped in their "narcissistic experience of recognizing their own culture in a cultural other" (Venuti, 1995:15). Foreignization, in Venuti's view, is "highly desirable today" and it appears to be more typical to certain European language contexts (Venuti, 1995:20). 
Domestication and foreignization strategies in translation, eventually, produce a text, or some elements of a text, in the target language which can be referred to as a type of literary transfer product (Pym,1992:3).

The analysis here, however, does not elaborate on the general concepts of translation and transfer but, rather, aims at a parallel comparison and contrasting of the English and Lithuanian translated texts of the same Korean novel. This way providing a bigger, distant picture for both English and Lithuanian "translation products" through a rather specific and limited approach to certain elements of translation. The paper will compare elements of nature translations in Kyung Sook Shin's novel Please Look After Mom (2011) into English and into Lithuanian Prašau, pasirūpink mama (2019), both texts translated from the Korean original. The focus of comparison will be nature scenes and nature items and the translators' decision to foreignize or domesticize their translations. The comparison of the translation strategies in translating nature scenes and nature items allows to conclude about the individuality of translators approaches to the values reflected in the narrative as well as to conclude about the distinction between the two products of translation.

\section{Two translations of Kyung-Sook Shin`s novel}

The novel by Kyung -Sook Shin Please Loo After Mom is a story told by multiple narrators, members of the same family - parents and their children. Part one is a second person narrative written from the point of view of the eldest daughter, an unmarried writer. Part two is written as a third person narrative from the position of the eldest son. Part three is the second person narrative again, the husband telling his story. Part four continues in the second person narrative, this time the narrator is So-nyo, the missing mother. The epilogue is narrated by the eldest daughter Chi-hon. The perspectives of the same events are manifold but they coexist within a saga of one family. The book Please Look After Mom translates a story of a woman's life into stories and lives of her family. It is a novel reflecting the chasm between generations in the present day Korea, the new roles of family members in society and the physical and moral loss of touch with the generation that gave themselves away in sacrifice for the better lives of their children. The younger generation, brought in a completely different rural milieu, making their new homes in the urban environment loses touch with their siblings, history, identity and nature.

The novel was an undeniable bestseller in Korea since the time of its publication 2008 and was translated into English by Chi-Young Kim in 2011. In 2012 the book was awarded Asia Man Booker Prize. As the Chair of Man Literary Prize professor David Parker, who must have read the English translation, then put it: "Please Look After Mom is a deeply moving, humane and intricately wrought book, at once culturally specific and universal." (MI, 2019). 
Lithuanian translation from Korean appeared in 2019 and was carried out by Martynas Šiaučiūnas Kačinskas and published by Baltos lankos. In his interview to a Lithuanian daily $15 \mathrm{~min}$., Kačinskas also emphasizes the universality of emotional impact produced by the novel by Kyung -Sook Shin (Kačinskas, 2019).

The global universal appeal of the book has been well recorded by the growing sales of the novel, ongoing translations of which a Lithuanian translation appearing in 2019 is an example. The immediate success of the story carried the story into another media - film production (2018), a translation of the audio-visual character, and in this way Kyung -Sook Shin`s Please Loo After Mom establishes itself as a literary product, which in Walkowitz opinion is "attuned to multipleformats, media, and languages." (Walkowitz, 2015:5).

\subsection{Transfer and translation strategies}

The construction of Kyung-Sook Shin's novel, the use of multiple narrators and their retrospective reference to the material nature-related objects suggest a case of ranslation or ,rather, transfer of objects (of nature) through time and from the traditional to the new generation culture (Pym, 2004:19). For example, in the memory of Chi-hon, the subject of the transfer, a material object, a communal well, is transferred from her parents` life experience in the village to her presentday visit to her parents` home:

\footnotetext{
"A long time ago there was a communal well right outside the back gate. The well was filled in when modern plumbing was installed in every house. You tapped the sturdy cement with your foot, precisely where that abundant well used to be. You were overwhelmed with nostalgia. What would the well be doing in the darkness under the street, the well that had supplied water to all the people in the alley and still sloshed about? You weren 't there when the well was filled in. One day you went back for a visit and the well was gone, just a cement road where it had been. Probably because you didn't see the wellbeing filled with your own eyes, you couldn't stop imagining that the well was still there, brimming with water, under the cement." (Kyung-Sook Shin, 2011:20)

"Seniau prie pat vartelių buvo bendras kaimo šulinys. I̦ kiekvieną namą ịvedus vandentiekị, savaime suprantama, šulinị uždengè, o tu jị prisiminusi prieš įeidama pro vartelius netikètai stabtelëjai. Netgi pabandei kietą cementą pastuksenti koja. Tiesa, kad anksčiau čia buvo neišdžiūvantis šulinys? Keistai pasijutai. Kas tokioje tamsybeje dedasi tame šulinyje, kuris maitino visus šio skersgatvio žmones ir visada buvo sklidinas? Nematei, kaip ji uždengè. Tau po ilgo laiko grįžus ị mamos namus, šulinys jau buvo dingęs, jo vietoje driekèsi cementinis kelias. Mintis,kad po tuo cementu iki šiol turètų būti vandens sklidinas šulinys, tavęs neapleidžia greičiausiai todèl, kad savo akimis nematei, kaip jis parnyksta." (KyungSook Shin, 2019:26)
}

From a life-giving source value the well acquires in the transfer a meaning of a danger-spot lurking in the darkness of the night. This transfer of materiality from one generation to another generation is an important structural, meaningful and cultural message of intracultural translation that the book reveals. The transfer of material objects and their meanings: natural produce, descriptions of nature and even landscape marks that happens in the memories of the subjects -narrators of 
the novel indicate the importance of the changing nature of meanings they bring to the reading of the novel in the language it was written, in Korean. Although it will not be discussed within the framework of this paper, the observed transfers disclose dynamics of intralingual translation between the values of the following objects: descriptions of nature, natural produce and landscape marks.

Translation of these transferred values into other languages allows to recognize this value change in the text. The meanings of these objects, contrary to the general implication of the universal appeal of the novel, spell out the individual, culture related dynamics of change, the epitome of 'otherness' of the nature related objects and transfer of their value.

\subsection{Translations of nature objects}

\subsubsection{Translation of recycled nature}

The first instance of comparing nature elements in two translations of KyungSook Shin's novel Please Look After Mom, English translation, and Prašau pasirūpink mama, Lithuanian translation, will analyse the translation of the traditional Korean village produce and diet. The two examples refer to the image of the mother and they open the novel with a broad display of tastes, smells and colours of recycled nature in the cottage shed. The image is a visual metaphor to what was later mentioned in a novel by one of the grown-up family members: "Mom was the kitchen and the kitchen was Mom." (Kyung-Sook Shin, 2011: 55). The loss of this life-giving and recycling power uncovers other layers of the character of the mother. Further in the novel the character is transferred from this kitchen metaphor into other statuses of human experience. The portrait in the shed reveals the connection of the character with the nature:

\footnotetext{
English translation

"In the shed, Mom kept glass bottles of every size filled with (1) plum or wild strawberry juice, which she made (2) seasonally. Mom`s jars were filled to the brim with tiny (3) fermented croaker like fish or anchovy paste or fermented clams that she was planning to send to the family in the city. When she heard onions were good for one's health, she made onion juice, and before winter came, she made (4) pumpkin juice infused with (5) licorice. Your mom's house was like factory; she (6) prepared sauces and fermented bean paste and hulled rice, producing things for the family year-round.” (Kyung-Sook Shin, 2011:5)

\begin{abstract}
Lithuanian translation
"Daržinèje rikiavosi dideli ir maži stikliniai buteliai, kuriuose ji laikè (2) skirtingais metu laikais supiltą (1) abrikosu ar braškiu sirupạ. I jos ąsočius iki kraštų prigrūsta (3) raugintu geltonpelekiu korvinu, ančiuviu, jūru moliūsku. Išgirdusi, kad svogūnai labai sveika, jų išspausdavo; prieš pat žiemą, paruošusi (4) senų moliūgu sulčių, ì jas įdèdavo (5)

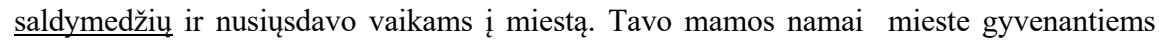
namiškiams buvo tarsi kokia gamykla, ištisus metus vis ką nors gaminanti. (6) Daranti soju padažă, raugianti čongukčanga, sverianti ryžius." (Kyung-Sook Shin, 2019:12,13)
\end{abstract}

The five (1/3/4/5/6) instances of nature objects that will be taken for comparison allow to propose that by and large domestication strategies in both translations presenting culturally acceptable and understandable translations from Korean 
food list into English and Lithuanian food menus. However, there are marked differences of choices of the strategies when comparing English and Lithuanian translations. For example, the English 'plum' in (1) 'plum or wild strawberry juice' can be translated by bilingual English-Lithuanian-English edictionary into 4 different meanings into Lithuanian: 1 slyvà (vaisius ir medis); French/dried džiovinta slyvà, cherry $\sim$ vyšninè slyvà. 2 razinà. raisin 3 tamsiai violètinè spalvà, dark purple. 4 gardùs kąsnẽlis; geriáusioji dalis; pelninga vietẽlè $\sim$ delicious bite, best part, income giving job (ežodynas, 2019). However, the Lithuanian translator uses a different fruit 'abrikosas' - apricot. For a Lithuanian farming tradition planting and rearing plums is more familiar than apricots. Apricots in this translation introduce a more exotic object, and a possibly foreignized item of translation. Without the Korean original it is difficult to determine if this is a case of domestication or foreignization of the translation. The observable fact is that the natural harvests are depicted differently in both translations and this situation signals that the translation of this object of nature (apricot/plum) opens up alternatives for the more or less 'exotic' style of this descriptive passage.

Item (1) in English and Lithuanian translation differs in its second component as well: 'wild strawberries/braškių'. Encyclopaedia Britannica distinguishes wild strawberries as a non-cultured growth: "Wild strawberries grow in a variety of habitats, ranging from open woodlands and meadows to sand dunes and beaches." (EB, 2019) Whereas Lithuanian 'braškès' translated by e-dictionary turn out to be:” bot. '(garden) strawberry' (ežodynas, 2019). Fruit combinations in English translation appear to yield juice while Lithuanian meaning informs us of syrup made of the fruit.

Interesting discrepancies in both translations appear in points (4) and (5). English (4) 'pumpkin juice' (5) 'licorice' versus Lithuanian (4) 'senų moliūgų sulčių', (5) 'saldymedžių'. Though 'pumpkin' and 'moliūgai' are the same fruit, yet Lithuanian translation adds the factor of ageing juice - 'senų moliūgų sulčių'. The recycling sophistication appears to be more emphasized in the Lithuanian translation of this element as of the production of fruit and berry syrup above.

No discrepancy is traced in the domesticated translation of 'licorice', English, and domesticated 'saldymedis', Lithuanian, However, 'licorice' in Encyclopaedia Britannica is described as "somewhat sweet and slightly bitter" (EB, 2019), whereas 'saldymedis' in Modern Lithuanian Dictionary (Dabartinės lietuvių kalbos žodynas) is characterised as "šaknys yra šleikščiai saldžios" [disgustingly sweet roots] (DLKŽ, 2015).

Point (6) produce, 'fermented bean paste' which in Lithuanian translation reads as 'čongukčangą' is of a special interest for the analysis. A very clearly cut turn towards domestication strategy is seen in the English translation where an explanation of the food process and content is given. Lithuanian translation resorts to extreme foreignization strategy presenting the reader with exotic sound of the dish without any additional information of its value. The word 'čongukčangas' is not even registered in the Modern Lithuanian Dictionary so the reader is rather 
abruptly faced with the "otherness" of the world of nature and culture in Korea and is given no explanation about this food.

Point (2), 'seasonally', English translation, and (2) 'skirtingais metų laikais', Lithuanian translation, reveals a different approach to time measure in both translations. The English translation stresses the recurrence of a certain season as the time for active recycling of the nature gifts, the Lithuanian translation allows to read the meaning of recycling routine that happens at different seasons, perhaps all year round.

The two translations of the same garden shed description with the introduction of the natural Korean cottage food menu seem to be following domestication strategies, presenting the reader with recognizable nature objects. However, the level of sophistication of recycling stands out in the Lithuanian translation more than in the English translation. The Lithuanian translation also shows a clear attempt of introduction of a foreign concept into the language, culture and value system - 'čongukčangas' - fermented bean paste. Whether the language and the culture accept this concept will become evident with time.

It is possible to assume that the English translation is accentuating the transfer step of the material objects in the memory of the younger generation of Koreans, the change of the meanings of these objects, therefore, the English translation blurs the "otherness" of harvested and consumed food as they remember it from their childhood and gives a more generic reference to the particular dishes grouping them with many other eating experiences: 'paste', 'juice', 'type'.

The tendency of the Lithuanian translation to give a greater degree of sophistication to food produce than the English translation may be considered as a foreignization strategy of Korean cottage cuisine.

\subsubsection{Translation of nature objects in their contact with the human activities}

The second sample of comparison is the interaction of the nature with the human physique through acculturation of nature or through a simple physical contact of a human body with nature. In the following example the English and Lithuanian translations of the opening lines of the letters the mother was sending to her son Hyong-chol and the panorama of the countryside she presented are quoted:

\footnotetext{
English translation

"Mom always followed "dear Hyong-chol" with something about the weather: "There are flowers now that it's spring." "It's summer so the (1) paddy bed is starting to dry and crack." "It's harvest season, and there are beans overflowing on the(2) paddy banks." (Kyung-Sook Shin, 2011:15)

Lithuanian translation

"Po kreipinio „Hjongčoliuk“ mama visuomet kalbėdavo apie orą. Čia atėjo pavasaris ir pražydo gèlès. Prasidèjo vasara, ir èmè skilinèti žemé (1) laukuose. Derliaus metas, (2) laukai pilni pupelių." (Kyung-Sook Shin, 2019:21)
}

The English 'paddy' as used in instances (1) and (2) is explained in Encyclopaedia Britannica as "small, level, flooded field used to cultivate rice in southern and eastern Asia" (EB, 2019) and online Merriam-Webster Dictionary states that 
'padi' must have stemmed from Malay 'padi' (MW, 2019). Clearly a long-time foreignization strategy is settled in the English translation tradition when writing of southern and eastern Asian agriculture.

Lithuanian translation tradition does not use another word for agricultural cultivation except for universal designation of the cultivated plot of land 'laukas' and the two instances in Lithuanian text show the resistant domestication strategy. However, the vision of a nature that yields harvest in different climatic conditions is better represented in the English translation with the foreignization strategy than in the Lithuanian translation following domestication strategy. Taken outside context Lithuanian excerpt does not indicate that the countryside is located in Asia at all.

The following excerpt where no human labour but a human physical contact with nature is involved follows a very different translation strategies both in English and in Lithuanian texts.

\footnotetext{
English translation

"You went across a (1) few paddies in the mountains that rimmed the back of the village and stepped onto a trail in the hills. Even though it wasn't a path people used, the trail was clear. (2) The thick layers of oak leaves on the ground cushioned your feet. Sometimes the branches that reached into the trail (3) hit your face. Mom, who was ahead of you, pushed the branches back for you. She let go of them after you walked through. A bird flew away." (Kyung-Sook Shin, 2011:46-47)

Lithuanian translation

"Perejusios kelias (1) kalno, stūksančio už namo, keteras, ịsukote ị kalno keliuką. Nors ir nevaikštomas žmonių, bet gerai pramintas kelias. Ten gulèjo (2) krūvos prikritusių dantytuju ir šeriuotuju ažuolu lapu, todèl takelis buvo minkštas. Išsikerojusios medžių šakos vis (3) brūžino veidą. Priekyje einanti mama kartkartėms šakas palenkdavo šonan. Tau praejus, paleisdavo. Netoliese purptelèjo paukštis.” (Kyung-Sook Shin, 2019:49)
}

The excerpt writes about a walk up the hill undertaken by the mother and her daughter. The trip sensually is described in a very different way in the English and in the Lithuanian texts. Sample (1) shows the relief of the path which in the English text looks like a terraced passage, i.e.: (1) 'few paddies in the mountains', in the Lithuanian text appears a mountainous ascend, i.e.: (1) 'kalno, stūksančio už namo, keteras'. Modern Lithuanian Dictionary (Dabartinès lietuvių kalbos žodynas) defines word 'ketera' as a mountain top (DLKŽ, 2019). Apart from relief, the path in the English and in the Lithuanian texts leads through a territory differently appropriated by the human being. The Lithuanian text writes of a more secluded passage, away from the village into the midst of wild nature.

Sample (2) is a radical domestication sample of translation of nature in the English text and a very awkward foreignization strategy sample in the Lithuanian text: (2)'The thick layers of oak leaves on the ground cushioned your feet.'; (2) 'krūvos prikritusių dantytujų ir šeriuotųjų ąžuolų lapų, todèl takelis buvo minkštas'.

The English translation mentions fallen 'oak leaves' without any further specification of the trees, but the Lithuanian text gives two species of the oak trees 
spotted in the particular Korean mountainous area 'dantytujų ir šeriuotųjų ąžuolų'. The implication for the English text is that the translator reduced the biological diversity and indicates merely a type of a tree - oak. The Lithuanian translation refers to the samples of the oak tree that are hardly known to grow in Lithuania or they are not known under those strictly botanical names. The two species of 'dantytụjų ir šeriuotujuc ąžuolų' are not introduced in the Indigenous Lithuanian Plants Name List (Vardynas, 2019). To a Lithuanian reader the created botanical names for the foreign species sound unfamiliar, foreign and within the sentence context they appear to be controversial. It is hard to imagine a 'cushioned feet' (softer and more comfortable) stepping on the 'rough edged (scalloped) and stubbly leaves'[dantytujų ir šeriuotujų] as the translation of the botanical species from Lithuania suggests. However, the Lithuanian foreignization strategy as opposed to English translation domestication strategy, informs a more curious reader with the diversity of flora in the mountainous areas in Korea. It is also possible to line the domestication strategy used with the transfer of material objects in the subject's, the narrator's mind. The tree, oak is reduced to a type without any specification. The diversity of nature is lost in the English translation. The Lithuanian translation leaves the subject, the narrator in much closer contact with the nature, the oak trees are named according to their species.

Another example of a human appropriation of the geographic space, global road tracking and depiction of a particular geographic location is seen in the translations of the following passage:

\footnotetext{
English translation

You stood up and hurried back to the road without bothering to brush the sand off your clothes. You decided against taking the plane to Seoul, and instead took a taxi to (1) Taejon and got on a train to (2) Chongup. Thinking all the while that you hadn't seen (4) Mom`s face in almost two seasons. (Kyung-Sook Shin, 2011:38)

Lithuanian translation

Atsistojai nuo smėlio. Nenusipurčiusi jo nuo užpakalio, nusisukai nuo jūros ir paskubomis nuejjai. Nusprendusi nebeskristi ị Seulą, iš miesto (1) P taksi nuvažiavai i miestą (2) L, ten persèdai i traukini, važiuojanti i miesta (3) J, kuriame gyvena mama. Galvodama, kad beveik šešis mènesius nesi (4) jos mačiusi. (Kyung-Sook Shin, 2019:42)
}

The English translation includes the names of the geographic locations, an inevitable foreignization strategy to keep the setting of the novel within the limits of the country. The trip is made to (1) Taejon and to (2) Chongup. The Lithuanian translation follows an odd obliteration of the location which cannot be recognized as a domestication strategy nor is it a proper foreignization strategy as seen in the English translation. Besides, the route is more complex it starts with the locus (1) $\mathrm{P}$, then moves to locus (2) L and finally arrives in locus (3) J. Even the initial letters of the proper names of the locations in the English and in the Lithuanian translation do not coincide. The interpretation and judgement of the strategy or of the translator's skill to see the ultimate message of the whole novel must be suspended here. Both translations have an aesthetic appeal, both translations could be enhanced with explanations 


\title{
2.2.3. Translation of the human body
}

The last group of comparisons is the presence of human body in the translated texts. Both the English and the Lithuanian translations with diligence describe the mother's blistered feet and the family`s disbelief that their mother could have such bodily flaws. It appears that the mother's body is an important family statement of the family condition. While the mother's body was causing no problems the family could live in a relatively peaceful state, when the messages of a tired, sick, with bleeding feet old woman started reaching the family members they refused to accept this information.

For translation comparison it is interesting to observe to what extent the mother image is given a character of flesh and blood in the English translation and in the Lithuanian translation.

A very detailed account of a wasted peasant woman's body, suffering from pains is given in the following excerpt:

\begin{abstract}
English translation
The early-morning wind borrowed into your clothes. You turned on the light in the yard and approached her. She was frowning, as she had done earlier asleep, (1) hand on her head. She was barefoot, (2) and her toes were curled under, perhaps from cold. The simple dinner and the talk you had shared while you strolled around the house together shattered. It was an early morning in November. You brought out a blanket and covered Mom with it. You brought socks and put them on her feet. And you sat next to her until she woke up. (KyungSook Shin, 2011:41)

Lithuanian translation

Rytmečio vẻjas ịsisuko ị drabužius. Uždegusi šviesą kieme, iškart pažiūrèjai suolelio, stovinčio daržinèje pusėn. Ji kaip ir dieną, miegojo suraukusi antakius ir (1) ant kaktos užsidejjusi rankas. Tikriausiai šalta, (2) nes visi dešimt koju pirštu suriesti. Atrodè, kad tas laikas, kai kartu su mama kukliai vakarieniavote, tie pasakojimai, kuriais su ja dalijaisi vaikščiojant aplink namą, subyrèjo ị šipulius. Buvo lapkričio parytys. Atnešei antklodę ir apklojai mamą. Kojinėmis apmovei basas kojas. Sėdejjai šalia, kol ji pasijuto geriau. (Kyung-Sook Shin, 2019:44)
\end{abstract}

Both translations make the reader follow the same cognitive direction starting with the feeling of cold and discomfort and closing the episode with the demonstrations of warmth and cosiness. The difference in the English and in the Lithuanian translation is in the plurality of the extremities, the greater epic detail and almost biological account of the body situation in the Lithuanian translation: (1) 'ant kaktos užsidejusi rankas'(pl. of hands) versus English (1) 'hand on her head'; (2) 'nes visi dešimt koju pirštu suriesti'( Engl. ten toes curled) versus English (2) and her toes were curled under, perhaps from cold.

Lithuanian translation is not so particular for details in all places of the novel where a human body is mentioned. In the following excerpt a body of the narrator mentioned only with reference to the 'lap' in the Lithuanian translation but in English translation the narrator is experiencing the warmth of sun on the 'back' and, assumingly, extends this warmth to her mom by supporting her head on the 
'lap'. The Lithuanian translation does not emphasize this transfer or rather the recycling of nature's energy through the narrator's (the daughter's) body.

\author{
English translation \\ With the setting sun (1) warming your back, you gazed down at Mom`s face cradled (2) on \\ your lap as if it were the first time you were seeing it. (Kyung-Sook Shin, 2019:25) \\ Lithuanian translation \\ Žvelgei ị vakarinès saulès nušviestą mamos veidą_(2) ant savo keliu, lyg ji būtų pirmą kartą \\ matomas žmogus. (Kyung-Sook Shin, 2019:30)
}

The English translation refers to the narrator's body by listing her (1) 'back' and (2) 'lap' while the Lithuanian translation only mentions the narrator's lap - (2) 'ant savo keliu'.

However, the English translation of body in the novel is generally given to a more metonymic reference of the body than the Lithuanian translation. An example of such treatment of the body is given in the above quote designating the travel route to mom's home and closing with the reference to mom's body:

English translation

Thinking all the while that you hadn`t seen (4) Mom`s face in almost two seasons. (Kyung-

Sook Shin, 2011:38)

Lithuanian translation

Galvodama, kad beveik šešis mėnesius nesi (4) jos mačiusi. (Kyung-Sook Shin, 2019:42)

The English translation uses a metonymy for the reference of the Mother 4) 'Mom's face in almost two seasons' while a Lithuanian translation speaks of the Mother with a simple reference of a $3^{\text {rd }}$ person feminine pronoun 'ji-jos' in the quote (4) 'jos mačiusi'.

It is possible to assume that an emphasis on a detail in the representation is rather related to the foreignization strategy as seen from the samples above, while the domestication strategy finds its expression in both Lithuanian and the English translations as a more general, without reference to particular details, reflection of the reality.

\title{
3. Conclusion
}

The analysis above attempted to look at the nature elements translations of the Korean novel by Shin Kyung-Sook Please Look After Mom (2011) into English by Chi-Young Kim and into Lithuanian by Martynas Šiaučiūnas Kačinskas Prašau, pasirūpink mama (2019).

In a brief summary it may be listed that foreignization and domestication issues are identified by comparing and contrasting the translations of the elements of nature in two translated texts,: in the Lithuanian version and in the English version of the same Korean novel. 
Lithuanian translations of a sophisticated food recycling procedure, introduction of foreign food names, botanical names of the tree species, the details with the numbers of extremities of the body are all aligned with the foreignization strategy.

However, when the details in describing nature are blurred or missed, in Lithuanian or English translations, as in the case of farming fields, the travel routes, single species of an oak tree or fruit species, it is possible to assume that the domestication strategy is enacted.

The English translations strategy of foreignization in translating nature scenes and nature items appears to find its expression in the traditionally foreignized southern and eastern Asian geographies, e.g. paddies, and in the metonymic reference to human bodies making them more obscure, less seen and identifiable.

The obliviated, blurred or explained by translation food recipes, tree species, indicate a tendency to use domestication strategy in translation in the English texts.

However, it must be admitted that the conclusions above are limited in their validity to the comparison of translation of nature elements in two translations Lithuanian and English of a Korean novel by Shin Kyung-Sook Please Look After Mom (2011). This analysis also reveals the choices of translation strategies of two individual translators Chi-Young Kim, an English translator, and Martynas Šiaučiūnas Kačinskas, a Lithuanian translator. The broader generalisations about the translation products cannot be reached but can be further advanced through similar comparison studies.

\section{References}

BU. Boston University, Why Study Comparative Literature? [online] Available from: https://www.bu.edu/wll/home/why-study-comparative-literature/[Accessed $30^{\text {th }} \quad$ December 2019]

DLKŽ. Dabartinès lietuvių kalbos žodynas. In Lietuvių kalbos išteklių informacinė Sistema [online] Available from: http://lkiis.lki.lt/home;jsessionid=7E3E3BC9C528EA4488628D042A7C27FE [Accessed 30 ${ }^{\text {th }}$ December 2019]

Encyclopædia Britannica, Inc. Encyclopaedia Britannica [online] Available from: https://www.britannica.com/ [Accessed 30 $0^{\text {th }}$ December 2019]

--, ežodynas.[online]Available from http://ezodynas.lt/lt/zodis/seriuotas 1461398 [Accessed 30 $30^{\text {th }}$ December 2019]

Laužikaitè, I. Vertėjas Martynas Šiaučiūnas-Kačinskas: „Ne žmonès renkasi Korèją, o Korèja renkasi žmones“. 15 min. 14 October 2018. [online] Available from: https://www.15min.lt/kultura/naujiena/literatura/vertejas-martynas-siauciunas-kacinskas-nezmones-renkasi-koreja-o-koreja-renkasi-zmones-286-1216756 [Accessed 30 ${ }^{\text {th }}$ December 2019]

MI.Man Group. [online] Available from: https://www.man.com/about-us [Accessed $30^{\text {th }}$ December 2019]

MW. Merriam-Webster Incorporated. Merriam-Webster Dictionary.[online] Available from: https://www.merriam-webster.com/dictionary/ [Accessed 30 ${ }^{\text {th }}$ December 2019]

Parks, Tim. Raw and Cooked. In The New York Review of Books. 20 June 2016. [online] Available from: https://www.nybooks.com/daily/2016/06/20/raw-and-cooked-translation-why-thevegetarian-wins/ [Accessed 05 ${ }^{\text {th }}$ September 2018] 
Pym, Anthony. 2018. Translation and Text Transfer An Essay on the Principles of Intercultural Communication. Tarragona: Intercultural Studies Group

Pym, Anthony. 1992. The Relations Between Translation and Material Text Transfer. Target 4(2). Available from:https://www.researchgate.net/publication/233546263 [Accessed $20^{\text {th }}$ August 2020] https://doi.org/10.1075/target.4.2.03pym

--,Sąrašas:Iliustruotas Lietuvos augalų genčių vardynas. [online] Available from: https://www.wikiwand.com/lt/S\%C4\%85ra\%C5\%A1as:Iliustruotas Lietuvos augal $\% \mathrm{C} 5 \% \mathrm{~B} 3$ gen $\%$ C4\%8Di\%C5\%B3 vardynas\# [Accessed 30 ${ }^{\text {th }}$ December 2019]

Shin Kyung-Sook. 2019. Prašau, pasirūpink mama. Baltos lankos.

Shin, Kyung-Sook. 2011. Please Look After Mom. Vintage.

Venuti, Lawrence. 1995. Translator`s invisibility. A History of translation. London and New York: Routledge.

Walkowitz, Rebecca L. 2007. Unimaginable largeness: Kazuo Ishiguro: Translation and the New World Literature. Novel 40.3 (Summer 2007), 217. https://doi.org/10.1215/ddnov.040030216

Walkowitz, Rebecca L. 2015. Born Translated: The contemporary Novel in the Age of World Literature. Columbia University Press. https://doi.org/10.7312/walk16594 